\title{
Corporate Social Responsibility Practices (CSR) and CSR Performance in Malaysian Automotive Industry
}

\author{
Nursyazwani Mohd Fuzi, Auni Fatin Nadia Chiek Desa, Siti Norhafizan Hibadullah, Farah \\ Izzaida Mohd Zamri
}

Dept. of Accounting and Finance, Universiti Pendidikan Sultan Idris 35900 Tanjung Malim, Perak, Malaysia

Tel: 60-012-586-0459Ｅ-mail: nursyazwanimohdfuzi@yahoo.com

\author{
Nurul Fadly Habidin (Corresponding author) \\ Dept. of Management and Leadership, Universiti Pendidikan Sultan Idris \\ 35900 Tanjung Malim, Perak, Malaysia \\ Tel: 60-017-571-7027Ｅ-mail: fadly@fpe.upsi.edu.my
}

Received: November 29, 2012 Accepted: December 17, 2012 DOI: 10.5296/ijafr.v2i2.2862

\begin{abstract}
Corporate Social Responsibility (CSR) is increasing interest in Malaysian automotive industry. The aim of this study is to review the structural relationship between CSR practices and CSR performance in Malaysian Automotive Industry. Thus, this paper seeks to explore the CSR practices (employee involvement, customer focus, environment, corporate governance, community and society, human right) and corporate social responsibility performance (environmental performance and social performance). This study concludes that CSR has an importance practices to improve performance. Based on the proposed conceptual model and reviewed, research hypotheses are being developed.
\end{abstract}

Keywords: CSR practices, Environmental performance, Social performance, Automotive 


\section{Mll Macrothink}

International Journal of Accounting and Financial Reporting

ISSN 2162-3082

2012, Vol. 2, No. 2

\section{Introduction}

The automotive industry is one of the most important in Malaysian manufacturing sector. Based in the ASEAN region with a population of more than 500 million people, Malaysia provides many opportunities for global automotive industry to establish manufacturing and operations in the country. Malaysia has built a real image of the national car manufacturer within the global automotive industry over the last two decades (Talib et al., 2012). Nowadays, the automotive industry is designated to increase the industrialization process and enable the country to achieve developed nation status by 2020 (MGCC, 2012). Based on the National Automotive Policy (NAP) in 2006 and 2009, the Malaysian government further confirmed the policy for the development of national automotive industry of OEMs, suppliers and related industries in the early 1980s (Wad and Govindaraju, 2011).

In Malaysia, CSR is one of the ways that corporations meet their obligations and employees as their large communities. Vicianova (2011) presented CSR as a commitment to improve community welfare by discretionary business practices and contributions of corporate. According to Rahim et al. (2011), CSR is the existence of an organization can be seen in the social contract that requires the corporation to take the interests of the community in decisions making. In Malaysia, CSR is one of the ways that corporations meet their obligations and employees as their large communities. On the other hand, CSR refers to a concept that has attracted the world-wide attention and acquired a new image in the global economy (Jamali et al., 2008). Jamali and Mirshak (2007) defined CSR as a set of management practices that ensures companies maximize the positive impact of operations on society. Besides that, corporate social responsibility is a weapon for competition and approach to improve the competitiveness by taking the opportunities and manage the risks associated with global trends (Will, 2007).

According to Bird et al. (2006), they found that the indication of the relationship between corporate social responsibility (CSR) activities within companies and their performance. In relation to that, the purpose of this study is to investigate the corporate social responsibility practices (CSR) and CSR performance in Malaysian automotive industry. Meanwhile, there are two elements of corporate social responsibility performance which are environmental performance and social performance.

\section{Literature Review}

\subsection{Corporate Social Responsibility Practices (CSR)}

CSR is most important part of character and culture of company management in Malaysian automotive industries. CSR refers to the responsibility of the community and the stakeholders that influence corporate policies and practices (Khanifar et al., 2012). Vicianova (2011) found that CSR is concerned to environmental and social aspects in automobile industry. In addition, CSR is the voluntary efforts taken by the business community to act with responsibility in relation to all stakeholders (Cetindamar and Husoy, 2007).

Based on previous study (Sweeney, 2009), CSR measures employee involvement, customer focus, environment, corporate governance, community and society, and human right. Definitions of the constructs of CSR practices incorporated in Table 1. 
Table 1. Construct Definitions

According to Yilmaz (2008) CSR practice was taking responsibility to impact on employees, customers, communities and operational environment. Besides that, the benefits CSR also affect the society than the company and its shareholder (Vicianova, 2011). A summary of

\begin{tabular}{|l|l|}
\hline Construct & Definition \\
\hline $\begin{array}{l}\text { Employee } \\
\text { Involvement }\end{array}$ & $\begin{array}{l}\text { The degree of commitment and worked in organizations (Ali et al., 2011) and } \\
\text { related to commitment, focus effort and energy (Macey and Schneider, 2008). }\end{array}$ \\
\hline Customer Focus & $\begin{array}{l}\text { Assessment based on the customer purchase and use of good or service over } \\
\text { time (Luo and Bhattacharya, 2006) and customer involvement, customer } \\
\text { orientation (Zakuan } \text { et al., 2007). }\end{array}$ \\
\hline Environment & $\begin{array}{l}\text { Pollution prevention and control, protection of water resources, biodiversity } \\
\text { conservation, waste management, pollution management, and environmental } \\
\text { management (Crifo and Forget, 2012) and environment friendly products, } \\
\text { waste management hazards, use of chemicals, pollution, and recycling } \\
\text { (Bhattacharya and Sen, 2004). }\end{array}$ \\
\hline $\begin{array}{l}\text { Corporate } \\
\text { Governance }\end{array}$ & $\begin{array}{l}\text { The standards used and controlled by the companies (Jamali et al., 2008) that } \\
\text { include system of laws, regulations, and operating in the company (Nulawadin, } \\
\text { 2008) }\end{array}$ \\
\hline $\begin{array}{l}\text { Community and } \\
\text { Society }\end{array}$ & $\begin{array}{l}\text { A group of people sharing the same goals, interdependencies to meet the needs } \\
\text { and interact with each other (Ismail, 2009) }\end{array}$ \\
\hline Human Right & $\begin{array}{l}\text { Everyone has the right to just and favorable remuneration to ensure suitable } \\
\text { life of human dignity (Rabet, 2009) and focusing on human rights and } \\
\text { responsibilities for the fair distribution of society (Leisinger,2006) }\end{array}$ \\
\hline
\end{tabular}

CSR practice benefits is given in Table 2 .

Table 2. Benefit of CSR practices

\begin{tabular}{|c|c|c|}
\hline Category & Authors & Benefit of CSR practices \\
\hline \multirow[t]{4}{*}{$\begin{array}{l}\text { Employee } \\
\text { Involvement }\end{array}$} & $\begin{array}{l}\text { Ali et al. } \\
(2011)\end{array}$ & $\begin{array}{l}\text { Achieving corporate goals and customer services, hard-working, } \\
\text { loyal to the organization and make a positive impact on the success } \\
\text { of the organization. }\end{array}$ \\
\hline & $\begin{array}{l}\text { Stancu et al. } \\
(2011)\end{array}$ & $\begin{array}{l}\text { Impact on employees' commitment towards employer, quality of } \\
\text { product or service depends on the level of employee motivation } \\
\text { and training, enable the companies established a strong } \\
\text { relationship with internal stakeholders, and improved profit } \\
\text { margin. }\end{array}$ \\
\hline & $\begin{array}{l}\text { Sweeney } \\
(2009)\end{array}$ & Increase employee attraction, retention and motivation. \\
\hline & Jones & Management will be more efficient, improve the goals of managers \\
\hline
\end{tabular}




\begin{tabular}{|c|c|c|}
\hline & Kato $(2005)$ & and employees, and improve quality. \\
\hline \multirow[t]{4}{*}{$\begin{array}{l}\text { Customer } \\
\text { Focus }\end{array}$} & $\begin{array}{l}\text { Loureiro } \\
(2012)\end{array}$ & Increase the value-added and attracting consumers' awareness. \\
\hline & $\begin{array}{l}\text { Sweeney } \\
(2009)\end{array}$ & Improve sales and customer loyalty. \\
\hline & $\begin{array}{l}\text { Luo and } \\
\text { Bhattacharya } \\
(2006)\end{array}$ & $\begin{array}{l}\text { Long-term profitability and market value, the level of satisfaction } \\
\text { by products and services that socially responsible firms, and } \\
\text { increase customer knowledge. }\end{array}$ \\
\hline & $\begin{array}{l}\text { Classon and } \\
\text { Dahlstrom } \\
(2006)\end{array}$ & $\begin{array}{l}\text { Affect customers' perception of products or services, influence of } \\
\text { customer loyalty and profitability. }\end{array}$ \\
\hline \multirow[t]{3}{*}{ Environment } & $\begin{array}{l}\text { Crifo and } \\
\text { Forget (2012) }\end{array}$ & Reduce negative external effects (pollution abatement). \\
\hline & $\begin{array}{l}\text { Lyon and } \\
\text { Maxwell } \\
(2008)\end{array}$ & $\begin{array}{l}\text { Reduce cost and waste reduction; improve sales of } \\
\text { environmentally friendly products and social welfare. }\end{array}$ \\
\hline & $\begin{array}{l}\text { Sweeney } \\
(2009)\end{array}$ & Waste reduction, energy saving, and water conservation. \\
\hline \multirow[t]{2}{*}{$\begin{array}{l}\text { Corporate } \\
\text { Governance }\end{array}$} & $\begin{array}{l}\text { Wise and Ali } \\
\text { (2009) }\end{array}$ & $\begin{array}{l}\text { Improved global perception of business, increase competitive } \\
\text { advantage, and increase profitability. }\end{array}$ \\
\hline & $\begin{array}{l}\text { Riyanto and } \\
\text { Toolsema } \\
(2007)\end{array}$ & $\begin{array}{l}\text { CSR helps to solve the agency problems, and increase the } \\
\text { managers' effort. }\end{array}$ \\
\hline \multirow[t]{3}{*}{$\begin{array}{l}\text { Community } \\
\text { and Society }\end{array}$} & Ismail (2009) & $\begin{array}{l}\text { Creates sustainable development, improve the welfare of } \\
\text { employees and local communities. }\end{array}$ \\
\hline & $\begin{array}{l}\text { Sweeney } \\
(2009)\end{array}$ & Enable involvement of the local community. \\
\hline & $\begin{array}{l}\text { Uddin et al. } \\
\text { (2008) }\end{array}$ & $\begin{array}{l}\text { Develop relationships with all stakeholder groups; improve the } \\
\text { quality of the workforce and the local community. }\end{array}$ \\
\hline \multirow[t]{2}{*}{ Human Right } & $\begin{array}{l}\text { Weigel } \\
(2011)\end{array}$ & $\begin{array}{l}\text { Enhancing social justice programs, and improves human rights } \\
\text { considerations. }\end{array}$ \\
\hline & Rabet (2009) & $\begin{array}{l}\text { The prevalence of the human rights to justice over wealth creation, } \\
\text { and human rights influence the behavior of corporation. }\end{array}$ \\
\hline
\end{tabular}


2.2 The Positive Effect of Corporate Social Responsibility Practices (CSR) and Corporate Social Responsibility Performance (CSRP)

Study by Ioannou and Serafeim (2010) and Gholami (2011) stated that CSR performance focused on two dimensions: (i) environmental performance and (ii) social performance. They found the relationship between the social and environmental performance through operations, firm, product and market characteristics. Besides that, there was a strong correlation between the environmental and social performance. Environmental performance is creates a good environment (Purnomo and Widianingsih, 2012) and improve the competitiveness of company (Flammer, 2012). This also supports by Loureiro et al. (2012) that highlight CSR performance could improve environmental performance in automobile industry. Thus, CSR has a strong positive relationship in environmental performance.

CSR initiative enables the company to obtain benefit of CSR performance (Thiele et al., 2008). For example, Afonso et al., (2012) found that CSR has a positive relationship with social performance. This finding confirms that consumers are more vulnerable to products and services.

Based on the literature, there have been various measures of the CSR performance. A research finding of CSR performance is given in Table 3.

Table 3 . The research finding on corporate social responsibility performance

\begin{tabular}{|c|c|c|}
\hline Measure & Authors & Findings \\
\hline \multirow[t]{6}{*}{$\begin{array}{l}\text { Environmental } \\
\text { Performance }\end{array}$} & Loureiro et al. (2012) & $\begin{array}{l}\text { Consumers influences environmental performance, } \\
\text { and reducing risk through cleaner production and } \\
\text { energy efficiency. }\end{array}$ \\
\hline & $\begin{array}{l}\text { Purnomo and } \\
\text { Widianingsih (2012) }\end{array}$ & $\begin{array}{l}\text { To make investment decisions, and provide a positive } \\
\text { image for the company. }\end{array}$ \\
\hline & Flammer (2012) & $\begin{array}{l}\text { Improve green initiatives of company, and reduce } \\
\text { marginal returns. }\end{array}$ \\
\hline & Sweeney (2009) & Cost savings to improve environmental performance. \\
\hline & $\begin{array}{ll}\text { Ioannou } & \text { and } \\
\text { Serafeim }(2010) & \end{array}$ & $\begin{array}{l}\text { Improve corporate awareness through the } \\
\text { environment. }\end{array}$ \\
\hline & $\begin{array}{l}\text { Stanwick and Stanwick } \\
\text { S.A. (1998) }\end{array}$ & $\begin{array}{l}\text { Reduction of environmental pollution, and reduce } \\
\text { polluting activities. }\end{array}$ \\
\hline \multirow[t]{4}{*}{$\begin{array}{l}\text { Social } \\
\text { Performance }\end{array}$} & Afonso et al. (2012) & $\begin{array}{l}\text { Improve the company's financial, and positive on } \\
\text { sales. }\end{array}$ \\
\hline & $\begin{array}{l}\text { Ioannou and Serafeim } \\
(2010)\end{array}$ & Increase social welfare employees. \\
\hline & Yang et al. (2010) & $\begin{array}{l}\text { Increase the return on assets, improve competitive } \\
\text { advantages, and increase the company's image. }\end{array}$ \\
\hline & $\begin{array}{l}\text { Albinger and Freeman } \\
(2000)\end{array}$ & 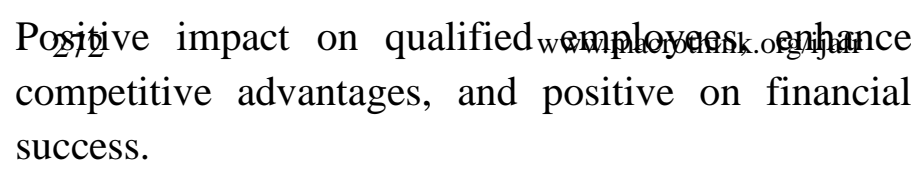 \\
\hline
\end{tabular}




\section{Macrothink}

International Journal of Accounting and Financial Reporting

\section{A Proposed Research Model}

The proposed research model aims to analyze the relationship between corporate social responsibility practices and corporate social responsibility performance for Malaysian automotive industries. This model as presented in Figure 1. To understand the relationship of CSR practice and CSR performance in Malaysian automotive industry, the following hypotheses were set up to be tested. According to the literature review, these hypotheses will be stated based on the numbering system from H1. This style of hypotheses statement is chosen due to the nature of answering hypotheses using structural equation modeling methods.

H1: $\quad$ There is a positive and direct significant relationship between CSR practices and CSR performance in Malaysian automotive Industry.

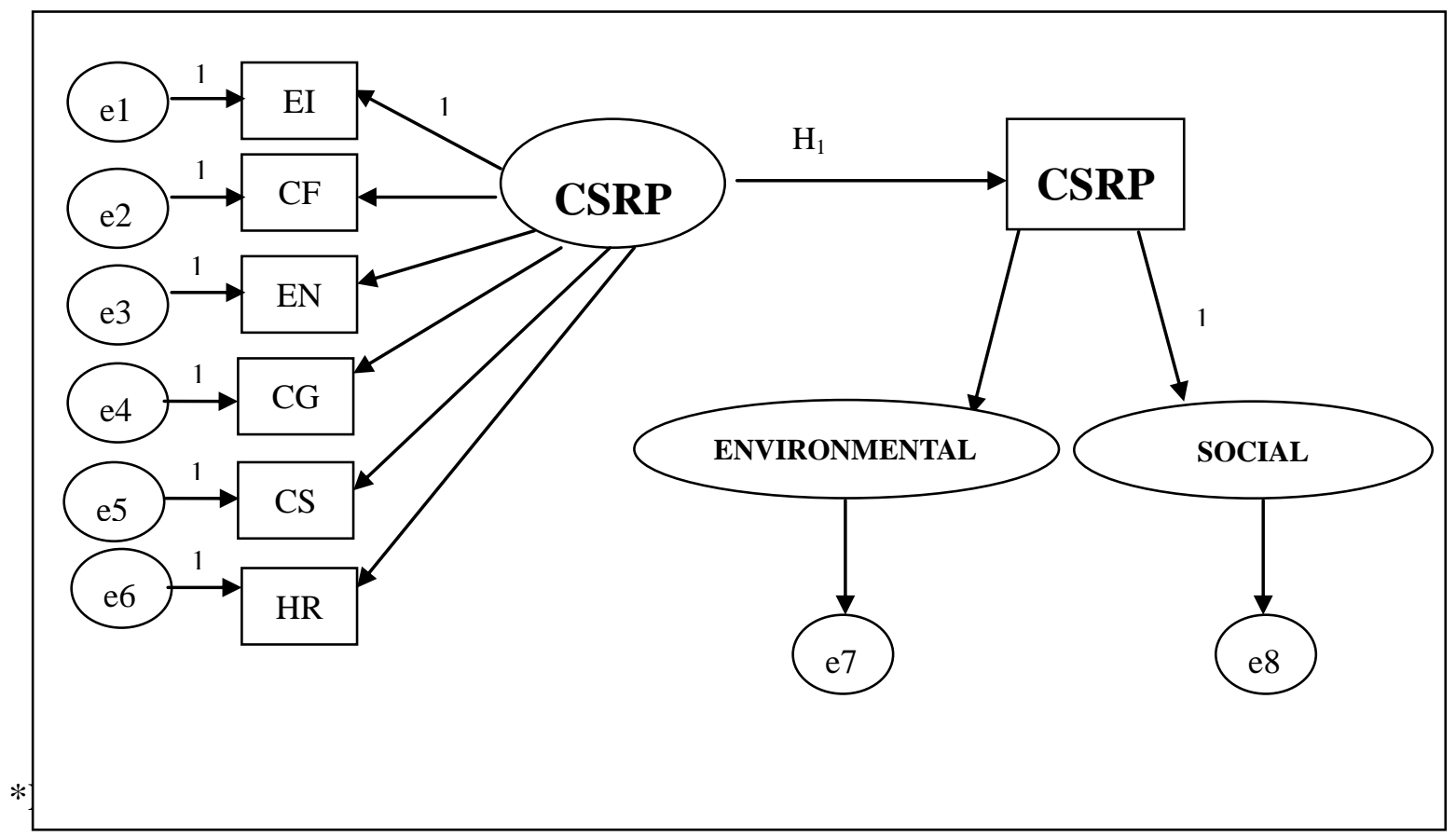

$\mathrm{CF}=$ Customer Focus, EN=Environment, $\mathrm{CG}=$ Corporate Governance, $\mathrm{CS}=$ Community and Society, HR=Human Right, CSRP=Corporate Social Responsibility Performance

Figure 1. Model of the study

\section{Methodology}

In this study, sampling method by using structured questionnaire. The population of this study comprised in Malaysian automotive industry. Questionnaires will distribute to respondents from the listing of automotive industry obtained from Malaysian Automotive Component Parts Association (MACPMA), Proton Vendors Association (PVA), and Kelab Vendor Perodua. To analyze the data, two statistical techniques were adopted.

Structural equation modeling (SEM) techniques was utilized to perform the required statistical analysis of the data from the survey. Exploratory factor analysis, reliability analysis and confirmatory factor analysis to test for construct validity, reliability, and measurements loading were performed. Having analyzed the measurement model, the structural model was then tested and confirmed. 


\section{MlMacrothink}

International Journal of Accounting and Financial Reporting

ISSN 2162-3082

2012, Vol. 2, No. 2

The statistical Package for the Social Sciences (SPSS) version 17 was used to analyze the preliminary data and provide descriptive analyses about thesis sample such as means, standard deviations, and frequencies. SEM using AMOS 6.0 will use to test the measurement model.

\section{Conclusion}

Based on the findings in the previous section obtained some conclusions. The aim of this study was to determine the factors of corporate social responsibility practices. In addition, CSR practices adopted different stakeholders to ensure the needs and interest. These findings allow us to conclude that CSR corporate social responsibility practice has a positive relationship between CSR performances in Malaysian automotive industry. A conceptual model has been proposed to examine the relationships between CSR practice and CSR performance in Malaysian automotive industry. In future agenda, a survey is designed in order to conduct an empirical research for examining survey's hypotheses. It is hoped that the important facts addressed in this study will be means whereby managers and researches will be able to investigate the CSR problem in Malaysian automotive industry with better awareness.

\section{Acknowledgement}

The researches would like to acknowledge the Ministry of Higher Education (MOHE) for the financial funding of his research thought Fundamental Research Grant Scheme (FRGS), and Research Management Centre (RMC), UPSI for Research University Grant (RUG).

\section{References}

Afonso, S. C., Fernandes, P. O., \& Monte A. P. (2012). CSR of Top Portuguese Companies: Relation between Social Performance and Economic Performance. World Academy of Science, Engineering and Technology, 66, pp. 853-857.

Albinger, H.C., \& Freeman, S.J. (2000). Corporate Social Performance and Attractiveness as an Employer to Different Job Seeking Population. Journal of Business Ethics, 28, pp. 243-253. http://dx.doi.org/10.1023/A:1006289817941

Ali, I., \& Ali, J.F. (2011). Corporate Social Responsibility, Corporate Reputation and Employee Engagement. Comsats Institute of Information Technology Lahore, Pakistan.

Bhattacharya, C.B., \& Sen, S. (2004). Doing Better at Doing Good: When, Why, And How Consumers Respond To Corporate Social Initiatives. California Management Review, 47(1), pp. 1-24. http://dx.doi.org/10.2307/41166284

Bird, R., Casavecchia, L., \& Reggiani, F. (2006). Corporate Social Responsibility and Corporate Performance: Where to Begin? University of Technology, Sydney and Bocconi University, Milan

Cetindamar, D. \& Husoy, K. (2007). Corporate Social Responsibility Practices and Environmentally Responsible Behavior: The Case of The United Nations Global Compact. Journal of Business Ethics, 76, pp. 163-176. http://dx.doi.org/10.1007/s10551-006-9265-4 
Classon, J., \& Dahlstrom, J. (2006). How Can CSR Affect Company Performance? A Qualitative Study of CSR and Its Effects. Master Thesis Business Administration, Faculty of Economy, Communication and IT, Karlstad University.

Crifo, P., \& Forget, V. (2012). The Economics of Corporate Social Responsibility: A Survey. Centre National De La Recherche Scientifique. PMid:22148517

Flammer, C. (2012). Corporate Social Responsibility and Stock Prices: The Environmental Awareness of Shareholders. MIT Sloan School of Management.

Gholami, S. (2011). Value Creation Model through Corporate Social Responsibility (CSR). International Journal of Business and Management, 6(9), pp. 148-154. http://dx.doi.org/10.5539/ijbm.v6n9p148

Ioannou, I., \& Serafeim, G. (2010). What Drives Corporate Social Performance? International Evidence from Social, Environmental and Governance Scores.

Ismail, M. (2009). Corporate Social Responsibility and Its Role in Community Development: An International Perspective. The Journal of International Social Research, 2(9), pp. 200-209.

Jamali, D., Safieddine, A.M., \& Rabbath, M. (2008). Corporate Governance and Corporate Social Responsibility Synergies and Interrelationships. Journal, 6(5), pp. 443-458.

Jamali, D., \& Mirshak, R. (2007). Corporate Social Responsibility (CSR): Theory and Practice in a Developing Country Context. Journal of Business Ethics, 72, pp. 243-262. http://dx.doi.org/10.1007/s10551-006-9168-4

Jones, D.C., \& Kato, T. (2005). The Effects of Employee Involvement on Firm Performance: Evidence from an Econometric Case Study. William Davidson Institute Working Paper No. 612.

Khanifar, H., Nazari, K., Emami, M., \& Soltani, H.A. (2012). Impacts Corporate Social Responsibility Activities on Company Financial Performance. Journal of Contemporary Research in Business, 3(9), pp. 583-592.

Leisinger, K. M. (2006). On Corporate Responsibility for Human Rights. Development Sociology, University of Basel.

Loureiro, S.M.C., Sardinha, I.M.D., \& Reijnders, L. (2012). The Effect of Corporate Social Responsibility on Consumer Satisfaction and Perceived Value: The Case of the Automobile Industry Sector in Portugal. Journal of Cleaner Production, 37, pp. 172-178.

http://dx.doi.org/10.1016/j.jclepro.2012.07.003

Luo, X., \& Bhattacharya, C.B. (2006). Corporate Social Responsibility, Customer Satisfaction, and Market Value. Journal of Marketing, 70, pp. 1-18.

http://dx.doi.org/10.1509/jmkg.70.4.1 
Lyon, T.P., \& Maxwell, J.W. (2008). Corporate Social Responsibility and the Environment: A Theoretical Perspective. Review of Environmental Economics and Policy, 1, pp. 1-22.

Malaysian-German Chamber of Commerce \& Industry, Market Watch 2012-The Malaysian Automotive and Supplier Industry (MGCC).

Nulawadin, N.S.J. (2008). The Relationship between Corporate Governance and Corporate Social Responsibility in Government Linked Companies in Malaysia. Master of Business Administration.

Purnomo, P.K., \& Widianingsih, L.P. (2012). The Influence of Environmental Performance on Financial Performance with Corporate Social Responsibility (CSR) Disclosure as a Moderating Variable: Evidence from Listed Companies in Indonesia. Review of Integrative Business and Economics Research, 1(1), pp. 57-69.

Rabet, D. (2009). Human Rights and Globalization: The Myth of Corporate Social Responsibility? Journal of Alternative Perspectives in the Social Sciences, 1(2), pp. 463-475.

Rahim, R.A., Jalaludin, F.W., \& Tajuddin, K. (2011). The Importance of Corporate Social Responsibility on Consumer Behavior in Malaysia. Asian Academy of Management Journal, 16(1), pp. 119-139.

Riyanto, Y.E., \& Toolsema, L.A. (2007). Corporate Social Responsibility in a Corporate Governance Framework. Department of Economics, Working Paper No. 0702.

Stancu, A., Grigore, G.F., \& Rosca, M.I. (2011). The Impact of Corporate Social Responsibility on Employees. International Conference on Information and Finance IPEDR, 21, pp. 11-16.

Stanwick, P.A., \& Stanwick, S.D. (1998). The Relationship between Corporate Social Performance, and Organizational Size, Financial Performance, and Environmental Performance: An Empirical Examination. Journal of Business Ethics, 17, pp. 195-204. http://dx.doi.org/10.1023/A:1005784421547

Sweeney, L. (2009). A Study of Current Practice of Corporate Social Responsibility (CSR) and an Examination of the Relationship between CSR and Financial Performance Using Structural Equation Modeling (SEM). Doctoral Thesis, Dublin Institute of Technology.

Talib, M.A., Munisamy, S., \& Ahmed, S. (2012). Automotive Parts Manufacturing Industry: Unraveling the Efficacious Quality Framework. Journal of Contemporary Research in Business, 4(3), pp. 217-226.

Thiele, S.R., Ball, K., \& Gillespie, M. (2008). Raising The Bar: From Corporate Social Responsibility To Corporate Social Performance. Journal of Consumer Marketing, 25(4), pp. 245-253. 
http://dx.doi.org/10.1108/07363760810882434

Uddin, M.B., Hassan, M.R., \& Tarique, K.M. (2011). Three Dimensional Aspects of Corporate Social Responsibility. Journal of Business and Economics, 3(1), pp. 200-212.

Vicianova, J. (2011). Corporate Social Responsibility in the Automobile Industry in Slovak Republic. Faculty of Economics, Department of Corporate Economics and Management, Matej Bel University.

Wad, P., \& Govindaraju, V.G.R.C. (2011). Automotive Industry in Malaysia: An Assessment of Its Development. International Journal Automotive Technology and Management, 11(2), pp. 152-171. http://dx.doi.org/10.1504/IJATM.2011.039542

Weigel, T. (2011). Is Sustainability Sustainable? Issues of Corporate Social Responsibility and Human Rights Sustainability in Modern Business. Journal of Undergraduate Research, pp. 1-7.

Will, M. (2007). Talking About the Future within an SME? Corporate Foresight and the Potential Contributions to Sustainable Development. Management of Environmental $\begin{array}{llllll}\text { Quality: An International Journal, } 19 & \text { (2), } & \text { pp. }\end{array}$ http://dx.doi.org/10.1108/14777830810856618

Macey, W.H., \&Schneider, B. (2008). The Meaning of Employee Engagement. Industrial and Organizational Psychology, $1, \quad$ pp. 3-30. http://dx.doi.org/10.1111/j.1754-9434.2007.0002.x

Wise, V., \& Ali, M.M. (2009). Corporate Governance and Corporate Social Responsibility in Bangladesh with special reference to Commercial Banks. Business Economics Working Paper Series, American International University-Bangladesh.

Yang, F.J., Lin, C.W., \& Chang, Y.N. (2010). The Linkage between Corporate Social Performance and Corporate Financial Performance. Journal of Business Management, 4(4), pp. 406-413.

Yilmaz, A.K. (2008). The Corporate Social Responsibility Practice in the Turkish Automotive Distribution Companies. International Journal of Business and Management, 3(6), pp. 139-147.

Zakuan, N.M., Yusof, S.M., \& Shamsudin, S. (2007). Implementation Of Quality Management Practices In Malaysian Automotive Industries: A Review. Regional Conference on Engineering Mathematics, Mechanics, Manufacturing \& Architecture.

\section{Copyright Disclaimer}

Copyright reserved by the author(s).

This article is an open-access article distributed under the terms and conditions of the Creative Commons Attribution license (http://creativecommons.org/licenses/by/3.0/). 